\title{
Por uma pedagogia da tolerância
}

Israel Alexandria Costa

Professor assistente na UFAL

Teresa Cristina Cavalcante de Albuquerque Professora do Curso de Pedagogia da UFAL

\section{Resumo}

O presente artigo tem por objeto principal a exploração da possibilidade da existência de um compromisso de engajamento de Jean-Jacques Rousseau na luta filosófica contra a intolerância. Através de um exame hermenêutico em torno do Émile on de L'Éducation, busca-se destacar e articular as reflexões rousseaunianas sobre a ideia de pitié naturelle de modo a sugerir que esta poderia substanciar um método pedagógico dirigido à formação de uma opinião e de uma vontade condizentes com a proposta de uma tolerância secularizada.

Palavras-chave: Tolerância; Educação; Religião.

\section{Resumé}

Le présent article a pour objet principal d'explorer la possibilité de l'existence d'un engagement de Jean-Jacques Rousseau dans la lutte philosophique contre l'intolérance. Moyennant d'un examen herméneutique autour d'Émile on de l'Éducation, on s'attache à souligner et à articuler les réflexions rousseauniennes sur l'idée de pitié naturelle, de façon à suggérer que celle-ci pourrait étayer une méthode pédagogique destinée à la formation d'une opinion et d'une volonté conformes à la proposition d'une tolérance sécularisée.

Mots-clé: Tolérance; Éducation; Religion.

Filosofia e Educação - ISSN 1984-9605 - Volume 4, Número 2

Outubro de 2012 - Março de 2013 


\section{Introdução}

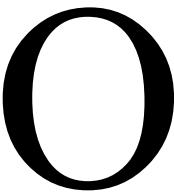

cronologista Michel Launay, no prefácio que acompanha uma célebre edição do Émile ou de l'Éducation em língua portuguesa, aludindo ao trabalho de Peter Jimack em La genèse et la rédaction de l'Émile de Jean-Jacques Rousseau. Étude sur l'histoire de l'ouvrage jusqu'à sa parution (1960), classifica a obra do genebrino como um romance sobre a educação — posto que se trata de uma narrativa fictícia sobre a amizade e o companheirismo entre um mestre e um discípulo chamado Emílio. Todavia, sinaliza também que se trata de um verdadeiro tratado de educação, visto que "sob a proliferação das ideias e das digressões, a trama é sólida, o plano é simples e claro" (LAUNAY, 1999, p. 12). Para demonstrar a existência desse plano, Launay vai à gênese do esquema que estrutura a obra e apresenta um fluxograma dos assuntos divididos em três numerações progressivas, com as seções primárias (livros) classificadas do seguinte modo: 1. sobre a tenra infância, infans, (0-2 anos): período que vai do nascimento à fala; 2. sobre a infância, puer, (2-12 anos): da fala à força; 3. sobre a adolescência (12-15 anos): da força à moral social; 4. sobre o homem: da moral social à moral cidadã; 5. sobre o cidadão: da moral cidadã à moral do sábio.

O comentador destaca, ainda, a seção especial inserida no livro 4, intitulada Profession de foi du Vicaire savoyard, que trata de religião e pode ser lida tanto como parte da educação moral do Emílio, quanto como uma inteira obra de filosofia. Ignora-se se no manuscrito ou primeiras versões impressas do Émile, o título desta seção especial encontrava-se destacado do corpo do texto, tal como na referida edição, que usou o recurso gráfico de um grande espaço em branco para inserir aí, em caixa alta, o título PROFISSÃO DE FÉ DO VIGÁRIO SABOIANO. Sabe-se, todavia, que no final

Filosofia e Educação - ISSN 1984-9605 - Volume 4, Número 2

Outubro de 2012 - Março de 2013 
da seção Rousseau (1969a, p. 635) registra: "transcrevi este texto... etc". Desse modo, ele deixa claro que pretendia tanto que não pairassem dúvidas sobre a ficticialidade e a autoria em relação às demais seções do Émile, quanto que não se acreditasse na ficticialidade e na sua autoria em relação à Profession de foi: "em vez de dizer-vos aqui por mim mesmo o que penso, dir-vos-ei o que pensava um homem de maior valor do que eu. Garanto a verdade dos fatos que vos serão narrados, eles realmente aconteceram" (ROUSSEAU, 1969a, p. 558).

Sempre surpreendendo ao elaborar retrocessos a gêneses que escapavam à mentalidade francesa setecentista, no início do Livro I, do Émile, Rousseau (1969a, p. 247) escreve:

nascemos fracos, precisamos de força; nascemos carentes de tudo, precisamos de assistência; nascemos estúpidos, precisamos de juízo. Tudo o que não temos ao nascer e de que precisamos quando grandes nos é dado pela educação.

Num século em que educação era pensada como algo de que a criança só teria necessidade depois de haver passado seis ou sete anos nas mãos de amas de leite ${ }^{1}$, a sugestão de que a educação fosse algo de que a criança precisaria ao sair do útero materno teve um efeito inovador nos costumes franceses do século XVIII. Na primeira parte do livro, ao propor como deve ocorrer a educação do zero aos dois $\operatorname{anos}^{2}$, Rousseau (1969a, p. 245) elege o seu auditório: "é a ti que me dirijo, terna e previdente mãe".

1 "Uma criança passa assim seis ou sete anos entre as mãos das mulheres, vítima dos caprichos delas e dos seus (...) Enfim, quando essa criança, escrava e tirana, cheia de ciência e carente de juízo, igualmente débil de corpo e de alma, é jogada no mundo, mostrando sua incapacidade, seu orgulho e todos os seus vícios, faz com que se deplorem a miséria e a perversidade humana. É engano; aquele é o homem de nossas fantasias; o da natureza é feito de outra maneira" (ROUSSEAU, 1969a, p. 261).

2 "Numa época em que a infância era tão pouco considerada, dedicar um capítulo de um livro aos dois primeiros anos de vida de uma criança é uma atitude mais que inovadora" (CERIZARA, 1990, p. 31).

Filosofia e Educação - ISSN 1984-9605 - Volume 4, Número 2

Outubro de 2012 - Março de 2013 
Esses dois adjetivos com que identifica o seu público remetem aos dois objetos principais da preocupação do retor: a ternura que nutre o corpo da criança, que precisa da provisão de um bom leite materno, e a previdência que, nutrindo o espírito, coloca-o na trilha da longa estrada em direção à futura realização de sua liberdade. E o futuro que o preceptor do romance tem em mente é o de cuidar para que o recém-nascido Emílio desenvolva o ser que ele já é desde o momento em que nasce, a saber: um ser humano.

$\mathrm{O}$ que justifica esse cuidado é a crença rousseauniana de que as instituições sociais de seu século impediriam o movimento que, em cada criança, encontra-se dirigida a esse fim interno - que é o de simplesmente ser humano — de modo a fazê-la esquecer de sua própria humanidade. A questão se torna tanto mais grave porque, ao retirar da criança esse fim que lhe é intrínseco, tais instituições não poriam no lugar qualquer outro fim positivo a que ela se destinaria ${ }^{3}$, de modo que o devir da criança equivaleria a uma experiência condutora ao nada.

No estado em que agora as coisas estão, um homem abandonado a si mesmo desde o nascimento entre os outros seria o mais desfigurado de todos. Os preconceitos, a autoridade, a necessidade, o exemplo, todas as instituições sociais em que estamos submersos abafariam nele a natureza, e nada poriam em seu lugar. Seria como um arbusto que o acaso faz nascer no meio de um caminho, e que os passantes logo fazem morrer, atingindo-o em

$3 \mathrm{O}$ que, na perspectiva rousseauniana, também não deixa de ser um defeito de educação. Tal se daria, por exemplo, quando se considera a criança como um ser imperfeito e imaturo em relação à perfeição e maturidade do adulto. Ante esse tipo de consideração, o Émile apresenta um interessante preceito "cada idade, cada estado da vida tem sua perfeição conveniente, o tipo de maturidade que lhe é própria. Ouvimos falar muitas vezes de um homem feito, mas consideremos uma criança feita: o espetáculo será mais novo para nós, e talvez não venha a ser menos agradável" (ROUSSEAU, 1969a, p. 417).

Filosofia e Educação - ISSN 1984-9605 - Volume 4, Número 2

Outubro de 2012 - Março de 2013 
todas as partes e dobrando-o em todas as direções (ROUSSEAU, 1969a, p. 245, grifo nosso $)^{4}$.

À primeira vista, essa reflexão parece entrar num confronto direto com a sugerida por Aristóteles em $A$ Política ${ }^{5}$ — de que o indivíduo que não se desenvolvesse entre os outros se desfiguraria num bruto. Mas esses "outros" não são os mesmos em ambos os casos. Em Aristóteles, são os outros da primeira e mais acolhedora forma de sociedade, que é a família; em Rousseau, são os outros da última e menos acolhedora forma de sociedade, que é a grande cidade moderna. O que o autor do Émile denuncia já no século XVIII é a vocação que tais grandes cidades têm em formar crianças abandonadas, não (apenas) no sentido prosaico da indigência econômica, mas sobretudo porque, na lógica da economia política moderna, a riqueza humana que se poderia extrair pela educação da criança passa a ser secundada pelo cuidado com superprodução da riqueza monetária e, desse modo, atropela-se impiedosamente a fragilidade humana que nasce no caminho por onde correm as máquinas dos tempos modernos.

Concebido para não ser vítima dessa máquina; para não sofrer a impiedade de uma sociedade corrompida e corruptora, a personagem Emílio recebe uma educação que o torna incapaz de ser impiedoso para com os

4 A perspectiva do cuidado educacional encontra-se, aqui, voltada exclusivamente para um indivíduo nascente que se vê ameaçado ante uma sociedade já instituída. "Na sociedade corrompida" - afirma Cerizara (1990, p. 41) - "a única coisa passível de salvação é o indivíduo". Tal projeto de salvação nasce da perspectiva que o educador lança em relação ao tempo cronológico. O olhar do historiador é retrospectivo: tal como no Discours sur l'origine, ele contenta-se apenas em descrever a sucessão dos vícios que entraram no coração humano, sem nada poder fazer a não ser acompanhar, como mero observador, o processo de depravação. A atenção do educador está, por sua vez, voltada para o futuro, seu olhar é previdente: tendo aprendido com os erros da história humana, impõe a si mesmo a tarefa de evitar que os desastrados e imprevidentes erros já cometidos repitam-se na história pessoal da criança que acaba de nascer.

5 "O homem é um animal cívico, mais social do que as abelhas e os outros animais que vivem juntos (...) Aquele que não precisa dos outros homens, ou não pode resolver-se a ficar com eles, ou é um deus, ou um bruto" (ARISTÓTELES, 1998, p. 5)

Filosofia e Educação - ISSN 1984-9605 - Volume 4, Número 2

Outubro de 2012 - Março de 2013 
outros: será um homem benevolente para com os da sua espécie, e um cidadão civilizado para com os que não acreditam nem pensam como ele ${ }^{6}$.

\section{A educação do homem}

Uma das noções mais importantes da antropologia de Jean-Jacques Rousseau é a pitié naturelle e cumpre reconduzir essa noção às suas origens numa abordagem que indique as possibilidades que ela apresenta em matéria de educação. Como é cediço, as duas primeiras e mais importantes referências a essa noção encontram-se respectivamente no prefácio e na primeira parte do Discours sur l'origine (1755), a saber:

Deixando de lado, pois, todos os livros científicos, que só nos ensinam a ver os homens como eles se fizeram, e meditando sobre as primeiras e mais simples operações da alma humana creio nela perceber dois princípios anteriores à razão, um dos quais interessa profundamente ao nosso bem-estar e à nossa conservação, e o outro nos inspira uma repugnância natural por ver perecer ou sofrer qualquer ser sensível e principalmente nossos semelhantes. Do concurso e da combinação que nosso espírito seja capaz de fazer desses dois princípios, sem que seja necessário nela imiscuir o da sociabilidade, parecem-me decorrer todas as regras do direito natural, regras essas que a razão, depois, é forçada a restabelecer com outros fundamentos quando, por seus desenvolvimentos sucessivos, chega a ponto de sufocar a natureza (ROUSSEAU, 1964a, p. $125)$.

Há [...] outro princípio que Hobbes não percebeu: é que tendo sido possível ao homem, em certas circunstâncias, suavizar a ferocidade de seu amor-próprio ou o desejo de conservação antes do

6 "Denomino intolerante em princípio todo homem que imagina que não se pode ser homem de bem sem acreditar em tudo o que ele acredita, e condena impiedosamente todos aqueles que não pensam como ele" (ROUSSEAU, 1969c, p. 1073).

Filosofia e Educação - ISSN 1984-9605 - Volume 4, Número 2

Outubro de 2012 - Março de 2013 
nascimento desse amor, tempera, com uma repugnância inata de ver sofrer seu semelhante, o ardor que consagra ao seu bem-estar [...]. Falo da piedade, disposição conveniente a seres tão fracos e sujeitos a tantos males como o somos: virtude tanto mais universal e tanto mais útil ao homem quando nele precede o uso de qualquer reflexão, e tão natural que as próprias bestas às vezes dão delas alguns sinais perceptíveis (ROUSSEAU, 1964a, p. 153, grifo nosso).

Salinas Fortes (1996, p. 57) pretende que a concepção rousseauniana de piedade seja uma capacidade de "sair de si e de se identificar com o outro", uma espécie de desespero de não querer ser eu (para dizer numa linguagem kierkegaardiana). Situando a concepção no interior da proposta de avaliar a origem do homem como pertencente ao conjunto das origens das espécies vivas que sobreviveram e se multiplicaram pela geração de indivíduos, a pitié naturelle nada mais seria que o amour de soi de uma determinada espécie, manifestada em cada indivíduo desta espécie. Nesse sentido, tal compaixão de que os animais compartilham não se confundiria com o instinto de sociabilidade. Tratar-se-ia, a pitié, de levar cada indivíduo não a uma associação ativa com o outro, mas de evitar causar-lhe um sofrimento que repercutiria sobre si mesmo enquanto espécie. Assim como o amour de soi levaria à conservação do indivíduo, a pitié, faculdade de compartilhar o sofrimento alheio, seria uma espécie de instinto de conservação mútua da espécie.

É em razão do caráter preservacionista da espécie que Rousseau considera ser a pitié naturelle um princípio útil ao homem. Nesses textos, a pitié aparece sob o estatuto de um princípio pré-reflexivo da alma humana que, temperando a ferocidade natural, age como um dos fundamentos de um direito natural do qual dão exemplo os animais, pois, segundo o autor do Discours sur l'origine, "um animal não passa sem inquietação ao lado de um animal morto de sua espécie" (ROUSSEAU, 1964a, p. 153).

Filosofia e Educação - ISSN 1984-9605 - Volume 4, Número 2

Outubro de 2012 - Março de 2013 
A animalidade ou a irreflexividade da pitié, enquanto elemento do direito natural, leva o autor a assumir algumas consequências avançadas para uma época cuja conquista mais alta foram os direitos humanos. Enquanto componente de um direito que nasce da sensibilidade, a pitié obriga os homens a um certo dever em relação ao animais pelo mero fato destes também possuírem sensibilidade, tal como assinalado no prefácio do referido Discours:

parece, com efeito, que, se estou obrigado a não praticar qualquer mal para com meu semelhante, é menos por ser ele um ser razoável do que por ser um ser sensível, qualidade que, sendo comum ao animal e ao homem, pelo menos deve dar a um o direito de não ser maltratado inutilmente pelo outro (ROUSSEAU, 1964a, p. 126).

Essas mesmas intuições são retomadas no projeto de educação de Emílio através de uma retórica de condenação ao carnivorismo:

[...] Que coragem de homem teve o primeiro que aproximou da boca uma carne morta, que quebrou com os dentes os ossos de um animal moribundo, que fez com que se servissem dos corpos mortos, cadáveres, e submergiu em seu estômago membros que, um instante antes, baliam, mugiam, caminhavam e viam. Como pôde sua mão enfiar um ferro no coração de um ser sensível? (ROUSSEAU, 1969a, p. 414).

Nesse mesmo projeto pedagógico, o discurso da pitié também passará por um apelo a um certo realismo ingênuo que faz das paisagens idílicas algo permeado de uma santidade que reclama um sentimento escrupuloso de horror às devastações das florestas e à escavação da superfície terrestre. No argumento utilizado para propor a Emílio a ocupação de marceneiro, evoca-se o horror dos trabalhos que exigem a destruição inescrupulosa e massiva das verdejantes paisagens naturais, a exemplo dos trabalhos de mineração: "não farei de vosso filho um ferrador, 
um serralheiro, um ferreiro; não gostaria de vê-lo em sua forja com a aparência de um ciclope" (ROUSSEAU, 1969a, p. 477) 7 .

Em todo caso, tal poética idílica da pitié parece esperar, na educação emiliana, pelo momento de uma reflexividade capaz de ativá-la, de transformá-la em virtude social de benevolência ativa. Entretanto, esse momento posterior, racional e reflexivo não garante, por si só, o desenvolvimento dessa virtude. Para o autor, o modo como a vida social se desenvolve constitui a experiência central de formação da razão, e esta, quando mal conduzida, pode atrofiar o instinto natural da compaixão: uma boa racionalidade depende de uma boa socialidade, conforme assinala o autor de Le rationalisme de Jean-Jacques Rousseau, que assevera estarmos diante de uma filosofia em que "sociabilité et rationalité sont inséparables" (DERATHÉ, 1948. p. 172).

E Rousseau compreende que a boa condução, uma boa educação, é aquela que, recusando aceitar os dogmas que fixam a perversidade intrínseca do coração humano, torna os princípios da boa vontade natural o fundamento da regras da socialidade e da racionalidade. Uma vez livre para dar vazão ao seu instinto natural de piedade, o homem não precisa se afastar de si mesmo para fazer irromper a piedade; uma vez que a piedade é natural e imanente, o homem não precisa de qualquer apoio de uma transcendência exterior para praticá-la. Não precisa de deuses! Em outras palavras, não precisa ser devoto para ser piedoso. Se a verdadeira prática piedosa dos homens tem sua base num sentimento inato de boa vontade, a chamada piedade devota pela qual o homem estabelece um cálculo mercantilista de

7 Nos Rêveries, o mesmo horror às minas é evocado: "lá, pedreiras, abismos, forjas, fornos, um conjunto de bigornas, de martelos, de fumaça e de fogo substituem as doces imagens dos trabalhos campestres. Os rostos lívidos de infelizes que definham nos infectos vapores das minas, negros ferreiros, horríveis ciclopes são o espetáculo que o conjunto das minas substitui, no seio da terra, ao da verdura e das flores, do céu azulado, dos pastores apaixonados e dos trabalhadores robustos da superfície" (ROUSSEAU, 1959b, p. 1066).

Filosofia e Educação - ISSN 1984-9605 - Volume 4, Número 2

Outubro de 2012 - Março de 2013 
interesses em relação aos deuses torna-se uma vã e falsa piedade e, sob tal ótica, Rousseau não faz mais que reabilitar a crítica platônica à concepção vulgar de piedade. No diálogo Eutífron, Sócrates, o porta-voz de Platão, contesta a equivocada noção eutifroniana de piedade:

SÓCRATES - Mas pedir aos deuses o que devemos pedir, não é precisamente solicitar destes aquelas coisas de que temos necessidade?

EUTÍFRON - Que mais poderia ser?

SÓCRATES - E, ainda, oferecer-lhes os presentes devidos não é dar-lhes aquilo que necessitam? Posto que não seria próprio de um homem inteligente dar presentes a quem não tem necessidade deles.

EUTÍFRON - Dizes a verdade, Sócrates.

SÓCRATES - Mas, neste caso, Eutífron, a piedade se converteria numa técnica comercial que regulasse as trocas entre os deuses e os homens (PLATÃO, Eutífron, 14a-e).

Cônscio de que os princípios do amour de soi e da pitié jazem na estrutura irreflexa e insociável do homem, Rousseau não atribui a eles a determinação do caráter e do alcance das regras sociais humanas na história, as quais se deveriam às inúmeras causas fortuitas. No Discours sur l'origine fora possível imaginar as causas fortuitas que levaram o homem a sufocar a pitié pelo alastramento da desigualdade e da intolerância. Em seus escritos de si, mais exatamente na sexta caminhada dos Rêveries (1776), lamentando-se contra o modo como agiam os homens de seu tempo, capazes de distorcerem os atos genuinamente piedosos levando-os, por meio de encadeamentos sociais, a produzirem atos genuinamente perversos, ele confessa:

tive a oportunidade de saber que todas as tendências da natureza, sem excetuar a própria beneficência, usadas ou seguidas na sociedade, sem prudência e indiscriminadamente, mudam de natureza e se tornam muitas vezes tão prejudiciais quanto eram

Filosofia e Educação - ISSN 1984-9605 - Volume 4, Número 2

Outubro de 2012 - Março de 2013 
úteis em sua primeira orientação (ROUSSEAU, 1959b, p. 1052, grifo nosso).

Será no Émile que o autor mostrará como a prudência enquanto cuidado e controle contra o advento de causas fortuitas que sufocam ou mudam a natureza poderia promover uma educação para a benevolência de modo a que o desenvolvimento da racionalidade/socialidade estivesse em conformidade com a boa pitié. Longe de pretender que Emílio seja um solitário, o autor postula que a pitié se desenvolva no pupilo de forma a que ele se torne sociável de um modo radical. Para tanto, Rousseau observa ser o apego social desenvolvido a partir da comunidade das nossas necessidades, uma forma menos humana e menos garantida do que o apego nascido da comunhão das nossas misérias, ao qual se agregaria mais facilmente o sentimento da compaixão natural:

[...] nos apegamos a nossos semelhantes menos pelo sentimento de seus prazeres do que pelo de seus sofrimentos, pois vemos muito melhor nisso a identidade de nossas naturezas e as garantias de seu apego por nós. Se nossas necessidades comuns nos unem por interesse, nossas misérias comuns unem-nos por afeição (ROUSSEAU, 1969a, p. 503).

No decurso da obra, essa afeição se faz acompanhar da irrupção de uma piedade que se manifesta numa dupla tendência: ora como um sair de si que termina na dissolução do indivíduo em favor do outro, ora como um entrar em si que termina na concentração do indivíduo em seu próprio eu. Tratando de um dos movimentos naturais da piedade, o autor escreve: "como nos deixaremos comover pela piedade, a não ser saindo de nós mesmos e identificando-nos com o animal que sofre e deixando, por assim dizer, nosso ser para assumir o seu?" (ROUSSEAU, 1969a, p. 505). Em outro momento, a descrição do modo como o indivíduo experimenta a piedade revela que esta é considerada também um recolhimento para dentro

Filosofia e Educação - ISSN 1984-9605 - Volume 4, Número 2

Outubro de 2012 - Março de 2013 
de si: "[...] a piedade é doce porque ao nos colocarmos no lugar de quem sofre sentimos, no entanto, o prazer de não sofrer como ele. [...]"(ROUSSEAU, 1969a, p. 503).

Entretanto, o que prevalece no tratado educacional do genebrino é a recusa em situar a individualidade prudente em apenas uma dessas duas tendências. Ao caracterizar a epiderme da piedade prudente o autor evita situá-la como dissolução ou como concentração do eu para situá-la como uma espécie de razão que comporta, ao mesmo tempo, um cuidado com o eu e com o outro. Desse modo, a piedade que se manifesta no Emílio não é mais a piedade do direito natural propriamente dito, mas de um direito natural racional: distinção que se encontra assinalada pelo próprio autor numa observação apresentada no Essai sur la forme de la République:

protegidos pela sociedade da qual somos membros, ou na qual vivemos, a repugnância natural de fazer o mal não mais se encontra equilibrada em nós pelo receio de recebê-lo. Somos inclinados pela natureza, pelo hábito e pela razão de usar com os outros homens um pouco como com os nossos concidadãos e desta disposição reduzida em atos nascem as regras do direito natural racional, diferente do direito natural propriamente dito, que se funda apenas num sentimento verdadeiro, mas muito vago e muitas vezes sufocado pelo amor de nós mesmos (ROUSSEAU, 1964b, p. 329 , grifo nosso) ${ }^{8}$.

Efetivamente, a compaixão experimentada por Emílio, apesar de brotar de uma fonte natural, tem seu desenvolvimento completamente alterado pelos artifícios do preceptor e não se identifica com a compaixão que o homem natural sentiria. Trata aqui de uma pitié desenvolvida mediante uma certa racionalidade, uma certa socialidade que se dirige à

8 Embora essa leitura, que faz do natural ser sinônimo de racional, seja menos visível na última versão do Contrato, a sinonímia pode ser percebida, como fez Émile Durkheim (1956, p. 3) ao comentar sobre o significado do postulado rousseauniano de que a sociedade do contrato deve estar assentada na natureza: "mais c'est que, ici, naturel est synonyme de rationnel".

Filosofia e Educação - ISSN 1984-9605 - Volume 4, Número 2

Outubro de 2012 - Março de 2013 
formulação de princípios de uma teoria da justiça. Eis porque Rousseau falará em sentimento relativo não genuinamente natural, mas conforme a ordem natural: "Assim nasce a piedade, primeiro sentimento relativo que toca o coração humano conforme a ordem da natureza" (ROUSSEAU, 1969a, p. 505). Um comentador de Rousseau destaca, em seu artigo Justiça e sentimentos morais, a natureza filosófica do problema que envolve essa passagem do sentimento de piedade à ideia da justiça:

Frequentemente lê-se o livro IV do Émile como uma análise da presença dos sentimentos morais nas relações entre os homens, onde a referência à piedade pode valer como um fundamento afetivo das virtudes, um senso de justiça que, uma vez generalizado, pode ser compreendido como um princípio de equidade e de justiça. O Émile tenta responder a um problema filosófico bem conhecido: como se passa de um senso de justiça a uma teoria da justiça; de uma percepção da injustiça a princípios da justiça? Em outros termos, pode-se afirmar uma continuidade entre a esfera dos sentimentos (particularmente os sentimentos morais) e a esfera dos princípios que elaboram um ideal da justiça? (BRUGÈRE, 2010, p. 181).

O problema e o desafio colocados por Brugère são tarefas que uma teoria pedagógica rousseauniana deverá responder e que se tornam especialmente importantes quando se trata de dirigir tal pedagogia à formação de opinião e vontade de tolerância. Rousseau esboça as dificuldades gerais do problema ao descrever o modo como Emílio torna-se capaz dessa piedade, por assim dizer, racional. Nesse esforço, o preceptor cuida de conciliar sensibilidade natural e imaginação. Para o fomento de tal sensibilidade, busca-se evitar tanto o excesso de rigor que embotaria os sentidos pela brutalidade, como o excesso de luxo e de indulgência que levaria à insensibilidade pelo tédio. Para tanto, o pupilo torna-se uma espécie de livre andarilho que, num clima temperado, passa pelas mais diversas experiências ante os elementos naturais. Em suas diversas fases de vida, Emílio é levado a experimentar o frio num contato com a neve; a fome

Filosofia e Educação - ISSN 1984-9605 - Volume 4, Número 2

Outubro de 2012 - Março de 2013 
em decorrência de um atraso na volta para casa; sente o terror repentino por se ver perdido durante uma incursão na floresta; o cansaço de ter percorrido grandes distâncias; em meio às brincadeiras de correr, cai e sofre escoriações. Todas essas experiências objetivam, além de integrar uma educação física um tanto espartana, forçar a irrupção de uma sensibilidade aos desconfortos que o preceptor julga ser necessários à vida humana e ativa. É nesse contexto que aparece a seguinte observação:

o homem que não conhecesse a dor não conheceria nem a ternura da humanidade, nem a doçura da comiseração. Seu coração não se emocionaria com nada, ele não seria sociável, seria um monstro entre seus semelhantes (ROUSSEAU, 1969a, p. 313).

É ainda no Livro IV, mais especialmente por ocasião da educação religiosa do Emílio, que ocorre a apoteose racionalista do desenvolvimento da piedade. Nesse momento, Rousseau cuida para que o seu Emílio seja especialmente susceptível de compaixão aos sofrimentos que nascem da discórdia e da desigualdade entre seus semelhantes, exigindo por sua vez que essa susceptibilidade converta-se em ação reparadora, ou seja, que a piedosa beneficência de Emílio transforme-se no que se poderia chamar de racionalidade terapêutica:

[...] não supus que ao ver infelizes ele só tivesse por eles aquela piedade estéril e cruel que se contenta com lamentar os males que pode curar. Sua beneficência ativa logo lhe dá luzes que com um coração mais duro ele não teria adquirido, ou então teria adquirido bem mais tarde. Se vê reinar a discórdia entre seus camaradas, procura reconciliá-los; se vê pessoas aflitas, informa-se a respeito de seus sofrimentos; se vê dois homens que se odeiam, quer conhecer a causa daquela inimizade; se vê um oprimido gemer pelas vexações do poderoso e do rico, procura saber de que modo reparam-se essas vexações, e no interesse que tem por todos os miseráveis, os meios de pôr um fim em seus males nunca lhe são indiferentes (ROUSSEAU, 1969a, p. 544). 
Tal piedade ativa, dirigida à paz e à igualdade, não se confunde de modo algum com a piedade particularista e meramente passiva do homme naturel. O estabelecimento de uma direção universal para o sentimento da piedade natural irrompida no Emílio é uma das preocupações do autor do tratado sobre a Educação, conforme se observa no seguinte preceito extraído do Livro IV: "para impedir que a piedade degenere em fraqueza, é preciso então generalizá-la e estendê-la a todo gênero humano" (ROUSSEAU, 1969a, p. 548).

É nesse ponto que o objeto da piedade dirá respeito a um misto de compaixão pela infelicidade da condição humana em geral e uma compreensão das causas dessa infelicidade. É o momento em que o pupilo verifica que é o amor pelas próprias opiniões e não o amor pela verdade que move os homens; é também o momento em que se inicia a jornada rumo à civilidade propriamente dita, especialmente no tocante ao tema da opinião.

\section{A educação do cidadão}

O componente tolerantista propriamente dito da educação do Emílio é a civilidade, que Rousseau faz ser precedida de uma educação religiosa dirigida à cidadania. $\mathrm{O}$ texto que trata de tal educação é o da Profession de foi du Vicaire savoyard, a seção especial do Livro IV cujo objetivo é associar a maturidade moral do aluno a um credo religioso puramente racional $^{9}$. Importa destacar que o objetivo de pensar uma religião racional é

9 Vem à tona, aqui, a querela sobre o racionalismo da obra de Rousseau, em que Robert Derathé, autor de Le rationalisme de Jean-Jacques Rousseau posta-se contra Pierre Masson, autor de La Religion de Jean-Jacques Rousseau, para quem, na Profession de foi du Vicaire savoyard, "ao falar da beleza do evangelho [e] da vida e morte de Jesus [...], Jean-Jacques encontrou a forma da sua consciência e o equilíbrio de seu pensamento" (MASSON, 1970, p. 41). Ante afirmações do gênero, Derathé declara que não se deve procurar nas palavras de Rousseau substratos sentimentaisreligiosos, mas uma racionalidade capaz de nada ceder à opinião, inclusive à opinião cartesiana de que a razão seria um bem equitativamente distribuído em todos os homens: "já tivemos a ocasião de assinalar que Rousseau rejeitava o axioma cartesiano e não admitia que a razão fosse igual em todos os homens" (DERATHÉ, 1948, p. 31),

Filosofia e Educação - ISSN 1984-9605 - Volume 4, Número 2

Outubro de 2012 - Março de 2013 
considerado pelo preceptor do Emílio como o mais difícil de ser alcançado na luta pelo esclarecimento; sabe que é preciso estar calçado de bons argumentos para enfrentar o convincente poder que os credos em matéria de religião exercem sobre os ditames da razão; "é sobretudo em matéria de religião que a opinião triunfa" (ROUSSEAU, 1969a, p. 558), diz o autor, confessando que entra na matéria como quem passa por um caminho de fogos recobertos por cinzas enganadoras. $\mathrm{O}$ racionalismo com que Rousseau reveste a seção da Profession de foi du Vicaire savoyard transforma-a numa verdadeira obra de filosofia iluminista sobre a religião, extrapolando o mero objetivo de servir como assunto da educação do Emílio. A história dos relatos de censura durante o período da Ilustração não deixa dúvidas de que a perseguição da Igreja contra o autor e a obra emiliana deu-se em razão desse trecho filosófico de cento e oitenta e um parágrafos acerca do qual o próprio Rousseau escreve, no final de sua vida: "obra indignamente desonrada e profanada na presente geração, mas que ainda pode fazer uma revolução entre os homens" (ROUSSEAU, 1959b, p. 1018).

Nos termos em que coloca o autor, o texto da Profession de foi cumpre a seguinte promessa do confessor, o vigário saboiano, feita ao confidente:

ver-me-ás, se não tal como sou, pelo menos tal como eu próprio me vejo. Quando tiveres estudado toda a minha profissão de fé, quando conheceres bem o estado de minha alma, saberás por que

visto que, para o genebrino, "os limites da razão variam com os indivíduos que se encontram, acerca desta, desigualmente dotados" (DERATHÉ, 1948, p. 31). Lê-se, de fato, nas Lettres écrites de La Montagne: "vossa razão pode ser superior à nossa; mas isto não que dizer que ela deva nos servir de lei" (ROUSSEAU, 1964e, p. 698). Parece, então, que o caminho em direção ao que haveria de decisivo em torno dessa querela e que Derathé tem a coragem de assinalar - reside no reconhecimento da liberdade como caractere essencial da razão rousseauniana, caso em que importa conferir grande peso à seguinte afirmação registrada nas referidas Lettres: "E tanto é da essência da razão ser livre que, se quisesse se submeter à autoridade, isso estaria além de suas possibilidades" (ROUSSEAU, 1964e, p. 713).

Filosofia e Educação - ISSN 1984-9605 - Volume 4, Número 2

Outubro de 2012 - Março de 2013 
me considero feliz e, se pensares como eu, o que deves fazer para sê-lo (ROUSSEAU, 1969a, p. 565).

Esta relação entre fé religiosa e felicidade reaparece na passagem em que o confessor descreve seu passageiro e involuntário momento de incredulidade e lança suspeitas contra o ceticismo sistemático em matéria de religião:

Apesar de ter muitas vezes passado por males maiores, nunca levei uma vida tão continuamente desagradável quanto nesses tempos de confusão e de ansiedade, em que, errando sem parar de dúvida em dúvida, eu só tirava de minhas longas meditações incertezas, obscuridade e contradições sobre a causa de meu ser e sobre a regra de meus deveres. Como se pode ser cético por sistema e de boa-fé? Não sou capaz de compreendê-lo. Ou esses filósofos não existem, ou então são os mais infelizes dos homens. A dúvida sobre as coisas que nos importa conhecer é um estado violento demais para o espírito humano; ele não resiste muito tempo nesse estado; acaba decidindo-se de uma maneira ou de outra e prefere enganarse a não crer em nada (ROUSSEAU, 1969a, p. 567). ${ }^{10}$

Postulando a impossibilidade de verificar se existem de fato verdadeiros ateus, o autor contenta-se apenas em julgar o discurso ateu, classificando-o como sintoma de hipocrisia e/ou de infelicidade. Em todo caso, Rousseau já assinalara na Lettre sur la Providence, que o discurso filosófico ateu não está isento de ser identificado com o da própria intolerância religiosa que pretende combater:

denomino intolerante em princípio todo homem que imagina que não se pode ser homem de bem sem acreditar em tudo o que ele acredita, e condena impiedosamente todos aqueles que não pensam como ele. Com efeito, os fiéis raramente têm a disposição de deixar os condenados às penas eternas em paz neste mundo; e um santo que acredita viver com réprobos habitualmente se antecipa ao ofício do diabo. E se houvesse incrédulos intolerantes que quisessem forçar o povo a não crer em nada, eu não os baniria

10 Trata-se, aqui, de uma mensagem dirigida contra o ateísmo enciclopédico, do qual d'Holbach seria o maior representante.

Filosofia e Educação - ISSN 1984-9605 - Volume 4, Número 2

Outubro de 2012 - Março de 2013 
menos severamente do que os que o querem forçar a crer em tudo aquilo que lhes agrada (ROUSSEAU, 1969c, p. 1073). ${ }^{11}$

Recusando a irreligião em vista de uma religião puramente racional, o vigário começa por fazer uma exposição de fé em que a moral parece ser a sua única preocupação religiosa e, ao término, o confidente sente, de algum modo, ter caído no "conto do vigário", isto é, termina por se sentir alvo de uma persuasão poderosa, pois a moral que o vigário termina por professar é puramente racional, e não religiosa (tal como ele entendia ser a instituição religiosa). O confidente se vê ante uma moral que, apesar de denominada "religiosa", nada deve a rituais, escrituras, cultos, milagres, predições, revelações, imagens etc. De um certo modo, a única coisa "religiosa" propriamente dita que permanece na exposição do vigário é a ideia de Deus, ainda assim, um ideia puramente racional, como se Deus não passasse de uma ideia da razão pela qual a própria razão se refere como a um ser mais perfeito $^{12}$. Em face dessa compreensão, o confidente replica, indagando por

$11 \mathrm{O}$ texto das Confessions aborda as polêmicas em torno da Encyclopedie como uma tempestade que teria colocado cristãos e filósofos como partidos mutuamente intolerantes (ROUSSEAU, 1959a, p. 435); também ao trecho da Lettre à Christophe de Beaumont, em que o autor declara: "o zelo pela salvação dos homens não é a causa das perseguições; são o amor próprio e o orgulho que as produzem" (ROUSSEAU, 1969b, p. 971). A esses trechos se poderia acrescentar um extraído do próprio opúsculo da Profession de foi du Vicaire: "onde está o filósofo que, por sua glória, não enganaria de bom grado o gênero humano? Onde está aquele que, no segredo de seu coração, se proponha um outro objeto que não seja distinguir-se? Contanto que se eleve acima do vulgo, contanto que empane o brilho dos concorrentes, que mais pede ele? O essencial é pensar de modo diferente dos outros. Entre os crentes ele é ateu; entre os ateus, ele seria crente" (ROUSSEAU, 1969a, p. 569).

12 Trata-se de uma alusão proposital a Descartes. Haveria um paralelo entre as noções de res cogitans cartesiana e de conscience rousseauniana, destacando que ambas designam o substrato subjetivo que se dirige em busca de uma perfeição apresentada como atributo da divindade. Essa perfeição assume, no primeiro caso, a forma de onisciência: a verdade em matéria de ciência que Descartes aponta como meta em seu Discurso sobre o Método; no segundo, tal perfeição assume a forma de independência: a verdade em matéria de moral que o Vicaire aponta como meta em sua Profession de foi: "se eu não tivesse paixões, eu seria, em minha condição de homem, tão independente quanto o próprio Deus" (ROUSSEAU, 1969a, p. 857).

Filosofia e Educação - ISSN 1984-9605 - Volume 4, Número 2

Outubro de 2012 - Março de 2013 
que o eclesiástico, sendo um profissional de uma religião de igreja, não professou nada além de uma moral rigorosamente racional (ou religião natural $^{13}$ ), ao que o vigário rebate:

Vês em minha exposição apenas a religião natural; é muito estranho que seja preciso outra. Por onde conhecerei essa necessidade? De que posso ser culpado ao servir a Deus de acordo com as luzes que ele dá ao meu espírito e de acordo com os sentimentos que inspira ao meu coração? Que pureza de moral, que dogma útil ao homem e honroso ao seu autor posso tirar de uma doutrina positiva que eu não possa tirar sem ela do bom uso de minhas faculdades? Mostra-me o que podemos acrescentar, para a glória de Deus, para o bem da sociedade e para meu próprio proveito aos deveres da lei natural, e que virtude farás nascer de um novo culto que não seja uma consequência do meu. As maiores ideias da divindade vêm-nos pela razão sozinha. Vê o espetáculo da natureza, escuta a voz interior. Deus não disse tudo a nossos olhos, à nossa consciência, ao nosso juízo? Que mais nos dirão os homens? Suas revelações só degradam Deus, emprestando-lhe paixões humanas. Longe de esclarecer as noções do grande Ser, vejo que os dogmas particulares os confundem; longe de enobrecêlos, os aviltam; aos mistérios inconcebíveis que o rodeiam, acrescentam contradições absurdas; tornam o homem orgulhoso, intolerante e cruel (ROUSSEAU, 1969a, p. 607, grifo nosso).

Respondendo ao confidente que seu método rigorosamente racional não entra em desacordo com a religião positiva adotada em sua prática profissional, o vigário passa a tecer considerações sobre as suas opiniões a esse respeito, destacando, sobretudo, que se recusa a admitir o que, para ele,

13 A reação do confidente se justifica por uma tradição enciclopédica que via na religião natural a expressão de um racionalismo cético cuja expressão literária é a obra Diálogos sobre a Religião Natural, de David Hume, na qual o personagem Filo, portavoz do ceticismo filosófico, assim situa o caráter antieclesiástico da religião natural: "A experiência atesta que a menor parcela de honestidade e benevolência naturais tem mais efeito sobre a conduta humana do que as mais pomposas considerações sugeridas pelas teorias e sistemas teológicos. A inclinação natural de uma pessoa exerce sobre ela uma influência constante, está sempre presente à mente e mescla-se a todas as suas idéias e decisões, ao passo que os motivos religiosos, nos casos em que chegam a ter algum efeito, operam apenas de maneira intermitente, e é muito difícil que o espírito venha a habituar-se completamente a eles" (HUME, 1992, p. 176).

Filosofia e Educação - ISSN 1984-9605 - Volume 4, Número 2

Outubro de 2012 - Março de 2013 
se constitui numa injusta autoridade que a igreja cristã, em nome de uma vã erudição, exerce sobre os povos:

se o filho de um cristão faz bem em seguir, sem um exame profundo e imparcial, a religião de seu pai, por que o filho de um turco faria mal em seguir a mesma religião de seu pai? Desafio todos os intolerantes a responder a essa pergunta como algo que satisfaça um homem sensato (ROUSSEAU, 1969a, p. 624).

Para refutar as tendências imperialistas pelas quais a igreja cristã empreende sua evangelização ofensiva à soberania dos povos não cristãos, Rousseau postula um argumento de natureza político-pedagógica para justificar porque cada povo deve ter a sua religião e ser feliz nela sem precisar comparar-se com a dos outros: trata-se da educação cidadã que começa quando a criança, incapaz de escolher uma opinião religiosa dentre as demais, simplesmente segue a mesma religião de seus pais e, assim fazendo, nada faz de errado porque, em todos os lugares, essa é uma prática comum. O problema reside quando o indivíduo erige explicações e comentários, transformando sua experiência político-religiosa local em conteúdo doutrinário que julga poder defender como sendo a única opinião que cristaliza a verdade universal. Tal intelectualização da vida religiosa, que converte "religião" em "opinião" e desigualdade, é considerada por Rousseau (1969a, p. 624) um dos motores da intolerância: "vê, meu filho, a que absurdo levam o orgulho e a intolerância, quando cada um quer seguir totalmente a sua opinião e crê ter razão contra o resto do gênero humano", diz o confessor ao seu confidente ao falar do seu retorno à verdadeira vida religiosa por ocasião de seu abandono das opiniões que adquiriu ao ler os livros da doutrinária cristã:

voltei atrás e limitei minha fé às minhas noções primitivas. Nunca pude acreditar que Deus me ordenasse, sob pena de ir para o

Filosofia e Educação - ISSN 1984-9605 - Volume 4, Número 2

Outubro de 2012 - Março de 2013 
inferno, ser douto. Assim, fechei todos os livros. Deles um só há que está aberto a todos os olhos: é o da natureza. É nesse grande e sublime livro que aprendo a servir e a adorar seu divino autor. Ninguém tem desculpas para não o ler, pois ele fala a todos os homens uma língua inteligível a todos os espíritos (ROUSSEAU, 1969a, p. 624).

Utiliza-se, aqui, o célebre argumento da consulta no livro da natureza para, indo além da recusa lockiana da mediação ${ }^{14}$ do príncipe em matéria de religião, recusar todo tipo de mediação social ou humana ${ }^{15}$. Agarrado a esta certeza quanto à existência de um fundamento esclarecido para a moralidade, o Vigário abandona os demais fundamentos oferecidos pela instituição religiosa, senão como falsos, pelo menos como duvidosos. Todavia, o tempo desta dúvida não é o mesmo da dúvida ocorrida no tempo anterior, de confusão e de ansiedade. No primeiro tempo, a dúvida se estendia aos fundamentos da moralidade - considerados pelo Vigário como os pontos essenciais da prática religiosa - e fora vivida como estado penoso no qual não desejara permanecer; no segundo tempo, a dúvida não mais se estende aos tais pontos essenciais e é vivida como estado de despreocupação no qual o Vigário passa a desejar permanecer:

Eis o ceticismo involuntário em que permaneci. Esse ceticismo, no entanto, não me é nem um pouco penoso, porque não se estende aos pontos essenciais da prática, e estou convencido sobre os princípios de todos os meus deveres. Sirvo a Deus na simplicidade do meu coração. Só procuro saber o que é importante para a minha conduta; quanto aos dogmas que não têm influência nem sobre as ações, nem sobre a moral, e com que tanta gente se atormenta, não me preocupo com eles (ROUSSEAU, 1969a, p. 627, grifo nosso).

14 "O direito ou a arte de governar não trazem consigo o conhecimento certo das restantes coisas e, sobretudo, da verdadeira religião" (LOCKE, 1965, p. 103).

15 Kant estenderá tal recusa à mediação da natureza e criará a ideia de uma lei moral fundada numa liberdade incondicionada.

Filosofia e Educação - ISSN 1984-9605 - Volume 4, Número 2

Outubro de 2012 - Março de 2013 
Ao se referir aos dogmas que não têm influência nem sobre as ações, nem sobre a moral, Rousseau circunscreve os limites das adiáforas (coisas indiferentes) em matéria de religião: é indiferente, nessa matéria, tudo o que não tem influência nem sobre as ações, nem sobre a moral. O que se insinua aqui é que a intolerância se deveria ao fato de tanta gente se atormentar com os dogmas relativos às coisas indiferentes enquanto esquece dos dogmas relativos ao essencial, que é o núcleo moral.

Contudo, ao lançar os olhos às religiões particulares e ao modo como esses dois tipos de dogmas costumam se articular de fato, o Vigário revela o seu otimismo ao perceber que aquilo que, na maioria dos casos, se costuma perceber como sendo uma perversa e demasiada atenção às adiáforas não passa, na verdade, de adaptações locais do núcleo moral ao clima, ao governo, ao gênio do povo ou a qualquer outra causa particular. Eis porque ele confessa:

Encaro todas as religiões particulares como instituições salutares que prescrevem em cada lugar uma maneira uniforme de honrar a Deus por um culto público, e que podem todas ter suas razões no clima, no governo, no gênio do povo, ou em alguma outra causa local que torna uma preferível à outra, conforme os tempos e os lugares (ROUSSEAU, 1969a, p. 627).

A prescrição, em cada lugar, de uma maneira uniforme de honrar a Deus por um culto público é, como já vimos, a tarefa do legislador, a figura extraordinária que tem a missão de "descobrir as melhores regras da sociedade que convenham às nações" (ROUSSEAU, 1964c, p. 381), conforme pretende o autor do Contrat Social, que, no capítulo da religião civil, também defende a tese da salutaridade das religiões particulares que prescrevem em cada lugar uma maneira uniforme de honrar a Deus por um culto público. É preciso insistir aqui que a religião particular não é em si mesma salutar, mas apenas quando promove uma maneira uniforme de

Filosofia e Educação - ISSN 1984-9605 - Volume 4, Número 2

Outubro de 2012 - Março de 2013 
honrar a Deus por meio de um culto público, querendo afirmar com isso que não haveria salutaridade se várias religiões particulares promovessem uma variedade de cultos particulares em conflito com a uniformidade do culto público. Portanto, a religião particular só é salutar quando torna-se direito divino positivo, quando encontra-se alicerçada num único país, quando possui seus dogmas, seus rituais, seu culto exterior prescrito por leis numa única nação que a cultua. É nesse ponto que o Vigário, em nome de uma educação religiosa voltada para a paz, julga dever remover desse direito divino positivo seu vício essencial da intolerância, propondo pôr no lugar o elemento da civilidade: "o dever de seguir e amar a religião de seu país não se estende aos dogmas contrários à boa moral, como o da intolerância. É esse dogma horrível que arma os homens uns contra os outros e torna-os todos inimigos do gênero humano" (ROUSSEAU, 1969a, p. 628).

\section{Conclusão}

A presente análise dos textos de Rousseau aponta, ora para a solidariedade do autor às demandas da luta contra a intolerância religiosa em seu século, ora para enunciados que antecipam a atual crítica à tradição enciclopedista, perfazendo no conjunto a proposta de uma civilidade secularizada na medida em que se entenda por secularização a fixação da ideia de tolerância como um esforço de aprendizagem que obriga ambas as tradições, a religiosa e a enciclopédica, a refletirem sobre seus respectivos limites. Esse convite à secularização pode ser extraído do texto pelo qual o confessor, no texto do Émile, fixa o término de sua profession: "ousa confessar Deus entre os filósofos; ousa pregar a humanidade entre os intolerantes" (ROUSSEAU, 1969a, p. 633).

Filosofia e Educação - ISSN 1984-9605 - Volume 4, Número 2

Outubro de 2012 - Março de 2013 


\section{Referências bibliográficas}

ARISTÓTELES. A Política. Tradução Roberto Leal Ferreira. 2. ed. São Paulo: Martins Fontes, 1998.

BRUGÈRE, Fabienne. Justice et sentiments moraux. In: MONDOT, Jean. Modernités de Rousseau - Revue Lumières; Publication du Centre interdisciplinaire bordelais d'étude des Lumières. Paraissant deux fois par na) Bordeux: Université Michel de Montaigne Bordeux 3, no 15, 1er semestre, 2010.

CERIZARA, Ana Beatriz. Rousseau: a educação na infância. São Paulo: Scipione, 1990, $174 \mathrm{p}$.

DERATHÉ, Robert. Le rationalisme de Jean-Jacques Rousseau. Paris: Presses Universitaires de France, 1948, 197 p.

DURKHEIM. Émile. Le Contrat Social de Rousseau. Édition électronique réalisée à partir du livre d'Émile Durkheim, Montesquieu et Rousseau: Précurseurs de la sociologie. Pages 115 à 198. Collection "Les classiques des sciences sociales". Disponível em: <http://bibliotheque.uqac.uquebec.ca/index.htm>. Acesso em: 13 maio 2004

FORTES, Luís Roberto Salinas. Rousseau: o bom selvagem. São Paulo: FTD, 1996, 119 p.

HUME, David. Diálogos sobre a Religião Natural. Tradução José Oscar de Almeida Marques. São Paulo: Martins Fontes, 1992, 187 p.

LAUNAY, Michel. Introdução ao Emílio, de J.-J. Rousseau. In: ROUSSEAU, J.-J. Emílio ou Da Educação. 2. ed. Tradução Roberto Leal Ferreira. São Paulo: Martins Fontes, 1999, p. 6-30.

LOCKE, John. Carta sobre a Tolerância. Tradução João da Silva Gama. Lisboa: Edições 70, 1965.

MASSON, Pierre-Maurice. La Religion de Jean-Jacques Rousseau. Genève: Slatkine Reprints, 1970.

PLATÃO. Eutifron ou da Religiosidade. In: Márcio Pugliesi e Edson Bini. São Paulo: Ática, 1997. Diálogos. Tradução

ROUSSEAU, Jean-Jacques. Discours sur l'origine et les fondemens de l'inégalité parmi les hommes. Paris: Gallimard, v. 3, 1964a, p. 131-223.

Du Contrat Social ou Essai sur la forme de la République. Paris: Gallimard, v. 3, 1964b, p. 281-335.

Du Contrat Social ou Principes du droit politique. Paris: Gallimard, v. 3, 1964c, p. 351-470.

Émile ou de l'Éducation. Paris: Gallimard, v. 4, 1969a, p. 241-868.

Les Confessions. Paris: Gallimard, v. 1, 1959a, p. 1-656.

Les rêveries du promeneur solitaire. Paris: Gallimard, v. 1, 1959b, p. 993-1100.

$925-1007$.

Lettre à Christophe de Beaumont. Paris: Gallimard, v. 4, 1969b, p.

Filosofia e Educação - ISSN 1984-9605 - Volume 4, Número 2

Outubro de 2012 - Março de 2013 
Lettre à Voltaire (18 août 1756) : Sur la Providence. Paris: Gallimard, v. 4, 1969c, p. 1057-1075. 685-897.

Lettres écrites de La Montagne. Paris: Gallimard, v. 3, 1964e, p. 